\title{
Task Force of the European Federation of Medical Informatics Journals: Background, Rationale and Purpose
}

\author{
Izet Masic ${ }^{1}$, Josipa Kern ${ }^{2}$, Jana Zvarova ${ }^{3}$, Simon de Lusignan ${ }^{4}$, Gaj Vidmar ${ }^{5}$ \\ Society for Medical Informatics of Bosnia and Herzegovina, Sarajevo, Bosnia and Herzegovina ${ }^{1}$ \\ Croatian Society for Medical Informatics, Zagreb, Croatia ${ }^{2}$ \\ Czech Society for Biomedical Engineering and Medical Informatics, Prague, Czech Republic ${ }^{3}$ \\ Division of Community Health Sciences, St George's, University of London, UK ${ }^{4}$ \\ University Rehabilitation Institution, Republic of Slovenia and Institute of for Biostatistics and Medical \\ Informatics, Faculty of Medicine, University of Ljubljana, Ljubljana, Slovenia ${ }^{5}$
}

\begin{abstract}
The paper presents an analysis of how EFMI disseminates new knowledge and of the active medical informatics journals in EFMI member countries, which was carried out as an outcome of the EFMI Council meetings in London in 2008, Sarajevo in 2009 and Antalya in 2009 . The analysis identifies eight active major informatics journals and several other publications. Most are subscription-based and published at least quarterly. There is a possibility for the editors to meet regularly and form a community of practice with the aim of further improving their effectiveness in disseminating new knowledge and best practice in medical informatics. It is feasible to share expertise and it may be possible to harmonise several aspects of preparation and submission of manuscripts so that some of the identified barriers in publishing are reduced. Keywords. EFMI, mission statement, task force of medical informatics journals
\end{abstract}

\section{INTRODUCTION}

The European Federation for Medical Informatics (EFMI) is a non-profit scientific and professional organization established in 1976 that today consists of 31 na- $^{-}$ tional members [1-4]. All European countries are entitled to be represented in EFMI by an appropriate national medical informatics society. The term 'medical informatics' is used to include the whole spectrum of health informatics and all its subdisciplines and allied disciplines. The Medical Subject Headings (MeSH) defines medical informatics as [4, 5]: 'The field of information science concerned with the analysis and dissemination of medical data through the application of computers to various aspects of health care and medicine.' This definition was introduced in 1987 as a MeSH term.

EFMI operates with a minimum of bureaucratic overhead with each national society supporting the federation by sending a representative to participate in the council. English has been adopted as the official language, although simultaneous translation is often provided for congresses in non-English speaking countries [6]. EFMI has 16 working groups: Smart Cards in Health Care 'CARDS'; Social Security and Welfare; Education in Health Informatics 'EDU'; Electronic Health Records 'EHR'; Evaluation and Assessment of Health Information Systems 'EVAL'; Informatics for Disabled People and Rehabilitation 'IDR'; Information Planning and Modelling in Health Care 'IPAM'; Libre/Free and Open Source Software 'LIFOSS'; Case-mix and Severity of Cases; Medical Informat- ics in Transition Countries 'MICIT'; Medical Imaging Processing 'MIP'; Natural Language Understanding 'NLU'; Nursing Informatics in Europe 'NURSIE'; Human and Organisational Factors of Medical Informatics 'HOFMI'; Primary Care Informatics 'PCI'; Safety, Security and Ethics 'SSE'; and Traceability 'TRA'.

To date, EFMI has organized 21 European congresses of medical informatics, including the Medical Informatics Europe (MIE) congresses in Cambridge (1978), Berlin (1979), Oslo (1988), Glasgow (1990), Vienna (1991), Jerusalem (1993), Lisbon (1994), Copenhagen (1996), Thessaloniki (1997), Ljubljana (1999), Hannover (2000), Budapest (2002), St. Malo (2003), Geneva (2005), Maastricht (2006), Gothenburg (2008) and Sarajevo (2009). The MIE 2011 conference will be held in Oslo. Traditionally, MIE conferences were not held in the year in which the International Medical Informatics Association (IMIA) organises its triennial conference MEDINFO [1]. EFMI has also started a new series of meetings: the Special Topic Conferences (STCs). The STC concept has the following components: a) organization should be done by a member so- 


\begin{tabular}{|c|c|c|c|c|c|c|c|c|c|c|c|}
\hline \begin{tabular}{|c|} 
EFMI \\
COUNTRY
\end{tabular} & $\begin{array}{l}\text { Journal } \\
\text { title }\end{array}$ & Publisher & $\begin{array}{l}\text { Editor-in- } \\
\text { Chief }\end{array}$ & $\begin{array}{l}\text { Established } \\
\text { in }\end{array}$ & \begin{tabular}{|c|} 
Issues \\
per year
\end{tabular} & Submission & $\begin{array}{c}\text { Web- } \\
\text { site }\end{array}$ & Language & $\begin{array}{c}\text { Field (MI } \\
\text { or/and other) }\end{array}$ & $\begin{array}{c}\text { Peer } \\
\text { reviewed }\end{array}$ & Financed by \\
\hline Austria & $\begin{array}{l}\text { Artificial Intelligence } \\
\text { in Medicine }\end{array}$ & Elsevier & $\begin{array}{l}\text { Klaus-Peter } \\
\text { Adlassnig }\end{array}$ & $\begin{array}{c}1989 \\
\text { ISSN 1386-5056 }\end{array}$ & 9 & email & yes & English & $\mathrm{MI}$ and other & international & subscription \\
\hline \begin{tabular}{|c|} 
Bosnia and \\
Herzegovina
\end{tabular} & Acta Informatica Medica & \begin{tabular}{|c|} 
AVICENA, \\
Sarajevo
\end{tabular} & Izet Masic & $\begin{array}{c}1993 \\
\text { ISSN 0353-8109 }\end{array}$ & 4 & email & yes & English & MI and other & international & subscription \\
\hline Croatia & $\begin{array}{c}\text { Bilten HDMI } \\
\text { (Bulletin of the CSMI) } \\
\\
\text { Medicinska informatika }\end{array}$ & CSMI & $\begin{array}{c}\text { Kristina Fišter } \\
\text { Josipa Kern }\end{array}$ & \begin{tabular}{|c|}
1992 \\
ISSN $1330-0253$ \\
1993 \\
ISSN $1330-1799$
\end{tabular} & $\begin{array}{c}2 \\
\text { bi- } \\
\text { annually }\end{array}$ & email & yes & $\begin{array}{l}\text { Croatian } \\
\text { English/ } \\
\text { Croatian }\end{array}$ & MI and other & national & \begin{tabular}{|c|} 
membership in the \\
society \\
ministry of science/ \\
publicity
\end{tabular} \\
\hline $\begin{array}{c}\text { Czech } \\
\text { Republic }\end{array}$ & \begin{tabular}{|c|} 
Lékar̆ a Technika \\
\\
European Journal for \\
Biomedical Informatics
\end{tabular} & EuroMISE & Karel Roubik & \begin{tabular}{|c|}
1970 \\
ISSN 0301-5491 \\
2005 \\
ISSN 1801-5603 \\
\end{tabular} & 4 & email & \begin{tabular}{|l|} 
yes \\
\end{tabular} & $\begin{array}{l}\text { Czech } \\
\text { English }+ \\
\text { other }\end{array}$ & \begin{tabular}{|c|} 
MI and biomedical \\
engineering \\
biomedical \\
informatics \\
\end{tabular} & international & $\begin{array}{c}\begin{array}{c}\text { public institutions/ } \\
\text { subscription }\end{array} \\
\text { other }\end{array}$ \\
\hline Denmark & newsletter & DSMI & - & - & - & - & yes & Danish/English & MI & national & public institutions \\
\hline France & $\begin{array}{l}\text { Informatique } \\
\text { et Sante }\end{array}$ & $\begin{array}{l}\text { Springer- } \\
\text { Verlag }\end{array}$ & $\begin{array}{c}\text { Patrice } \\
\text { Degoulet }\end{array}$ & - & 2 & email & \begin{tabular}{|l|} 
yes \\
\end{tabular} & $\begin{array}{l}\text { French/ } \\
\text { English }\end{array}$ & MI & national & $\begin{array}{c}\text { public institutions/ } \\
\text { subscription }\end{array}$ \\
\hline Germany & $\begin{array}{l}\text { Biometrie, Informatik } \\
\text { und Epidemiologie in } \\
\text { Medizin und Biologie }\end{array}$ & $\begin{array}{l}\text { Urban\& } \\
\text { Fischer } \\
\text { Verlag }\end{array}$ & - & - & - & email & yes & German & MI and other & national & $\begin{array}{c}\text { public institutions/ } \\
\text { subscription }\end{array}$ \\
\hline Ireland & Newsletter & & & & & & & & & & \\
\hline Israel & $\begin{array}{l}\text { ILAMI journal and The } \\
\text { Health Screen }\end{array}$ & - & - & - & 2 & - & - & - & MI and other & - & - \\
\hline Slovenia & $\begin{array}{l}\text { Informatica Medica } \\
\text { Slovenica }\end{array}$ & SMIA & Gaj Vidmar & \begin{tabular}{|c|}
1993 \\
ISSN 1318-2129 \\
(print) \\
ISSN 1318-2145 \\
(electronic)
\end{tabular} & 2 & email & yes & $\begin{array}{l}\text { English/ } \\
\text { Slovenian/ } \\
\text { other }\end{array}$ & $\begin{array}{l}\text { MI, biostatistics } \\
\text { and other }\end{array}$ & $\begin{array}{c}\text { international/ } \\
\text { national }\end{array}$ & $\begin{array}{l}\text { MI society } \\
\text { (SMIA) }\end{array}$ \\
\hline Spain & $\mathrm{I}+\mathrm{S}$ & SEIS & - & - & 6 & - & & - & MI and other & - & - \\
\hline Sweden & $\begin{array}{l}\text { Computer Methods and } \\
\text { Programs in Biomedicine }\end{array}$ & Elsevier & Torny Groth & \begin{tabular}{|c|}
1985 \\
ISSN 0169-2607
\end{tabular} & 12 & $\begin{array}{c}\text { paper/email// } \\
\text { online }\end{array}$ & yes & English & MI & \begin{tabular}{|l|} 
international \\
\end{tabular} & subscriptions \\
\hline Ukraine & $\begin{array}{c}\text { Clinical Informatics and } \\
\text { Telemedicine }\end{array}$ & UAMI & $\begin{array}{l}\text { Oleg Yu } \\
\text { Mayorov }\end{array}$ & $\begin{array}{c}2003 \\
\text { ISSN 1812-7231 }\end{array}$ & $2-3$ & email & \begin{tabular}{|l|} 
yes \\
\end{tabular} & $\begin{array}{l}\text { Ukrainian/ } \\
\text { English }\end{array}$ & MI and other & \begin{tabular}{|l|} 
international \\
\end{tabular} & public institution \\
\hline $\begin{array}{c}\text { United } \\
\text { Kingdom }\end{array}$ & $\begin{array}{c}\text { Informatics in Primary } \\
\text { Care }\end{array}$ & \begin{tabular}{|c|} 
Radcliffe \\
Publishing
\end{tabular} & $\begin{array}{l}\text { Simon de } \\
\text { Lusignan }\end{array}$ & \begin{tabular}{|c|}
1993 \\
ISSN 1476-0320
\end{tabular} & 4 & paper + online & yes & English & $\begin{array}{l}\text { PHC and Clinical } \\
\text { Informatics }\end{array}$ & \begin{tabular}{|c|} 
yes, \\
international
\end{tabular} & $\begin{array}{l}\text { PHCG BCS + } \\
\text { subscriptions }\end{array}$ \\
\hline EFMI & \begin{tabular}{|c|} 
International Journal of \\
Medical Informatics \\
Methods of \\
Information in \\
Medicine
\end{tabular} & Schattauer & $\begin{array}{c}\text { Charles Safran, } \\
\text { Jan Talmon }\end{array}$ & \begin{tabular}{|c|}
1961 \\
ISSN $1386-5056$ \\
\\
1962 \\
ISSN $0026-1270$ \\
\end{tabular} & 12 & paper/online & yes & English & MI & international & subscriptions \\
\hline
\end{tabular}

Table 1. EFMI member countries medical informatic journals

ciety possibly in combination with its annual meeting; b) EFMI Council meeting should be the integral part of STC; c) topic of the conference should be defined by the organizing member society; d) considering the topic, the relevant EFMI working groups should be engaged; e) contributions should be mostly by invitation; f) STCs are small 2-day conferences with $100+$ participants.

The first conference STC took place in Bucharest/Romania 2001, then in Nicosia/Cyprus 2002, Rome/Italy 2003, Munich/Germany 2004, Athens/Greece 2005, Timisoara/Romania 2006, Brijuni/Croatia 2007, London/United Kingdom 2008, and Antalya/Turkey 2009. In 2010, the STC will take place in Rejkjavik/Iceland, and in 2011 in Ptuj/ Slovenia. The proceedings of these conferences were usually published by Springer in the series 'Lecture Notes in Medical Informatics' and by IOS Press in the series 'Studies in Health Technologies and Informatics'. A selection of the best papers from the MIE conferences were published in a special volume of the International Journal of Medical Infor- matics and will be published in the Methods of Information in Medicine, while the special proceedings of STCs is published by IOS Press as collection of peer reviewed articles.

\section{REVIEW OF MEDICAL INFORMATICS JOURNALS IN EUROPE}

Medical informatics scientific and research production in Europe is growing both in quantity and quality. Promoting high-quality research is a major goal of EFMI [1, 4, 6]. EFMI has two highly respected official general journals, the International Journal of Medical Informatics (former title: International Journal of Bio-Medical Computing), currently edited by Charles Safran and Jan Talmon, and Methods of Information in Medicine, currently edited by Reinhold Haux. EFMI also publishes several sub-speciality official journals covering the spectrum of medical informatics sub-disciplines. The time-honoured method to disseminate high-quality scientific research is via the proceedings of the MIE annual conference. EFMI also plays a major role in education and in the harmonization of medical informatics sub-disciplines through the organization of STCs. Both MIE and STC proceedings are peer reviewed and published by IOS Press (Amsterdam, The Netherlands). Usually, MIE proceedings are indexed in Medline/PubMed. Most medical informatics journals are published in local languages, but many of them also incorporate English summaries or contain combined articles published in domestic and English language. Altogether, EFMI provides highly effective means for worldwide dissemination of medical informatics research conducted in Europe. However, in addition to the proceedings, journal editors have the opportunity to do more to disseminate knowledge and increase the understanding of our discipline.

\section{ANALYSIS OF PUBLISHING ACTIVITIES WITHIN EFMI MEMBERS}

Most of the information about the EFMI can be found on the official website (www.efmi.org). Furthermore, most of national societies have their own websites providing useful 
information about publications and meetings in EFMI member countries. Our analysis is based on the facts generated from EFMI database stored on EFMI website and collected from national representatives of EFMI member countries.

A search of Medline with the search terms 'EFMI' and 'European Federation for Medical Informatics' returns only 21 papers - 18 in medical informatics related journals: Informatics in Primary Care (6), International Journal of Medical Informatics (3), Methods of Information in Medicine (2), Studies in Health Technologies (6); and 3 in non-informatics/non-EFMI journals. Authors of the papers are: Blobel (2), De Lusignan (6), France (1), Horsch (1), McKeon (1), Masic (2), Michalas (2), Naszlady (1), Tallberg (1), Talmon (1), Trpisovský (1), van Goor (1), and Zvarova (1). Medline search using the term 'IMIA' was performed (for comparison) and 150 papers were found; the search term 'AMIA' resulted in 244 papers found. Most of EFMI papers are related to the activities of working groups - PCI is the most prominent $[5,6]$ - and relatively few initiatives at the level of the federation. Detailed analysis of EFMI website showed that only 14 of 31 members have their official scientific or professional medical informatics journal or newsletter listed (Table 1). Medical informatics journals have their articles published in English with three published in their national language. There are three journals published only as e-journals.

The frequency of ISSN registered publications varies: one journal is published biannually, two quarterly, one every two months, five journals are published 2-3 times per year, two journals monthly and one journal nine times per year. Medical informatics is the principal subject of all of the journals, but several of them focus on other sub-disciplines and allied disciplines. Most of the medical informatics journals are international publications, though three are restricted to national circulation. Two journals are financed by ministry of health and/or other public institutions, while others use subscription as the way of financing.

\section{MISSION STATEMENTS OF TASK FORCE OF EFMI JOURNAL EDITORS}

Editor-in-Chiefs of medical informatics journals are invited to create a joint mission statement and set out the objective and purpose of all EFMI journals. We believe that the joint statement will foster the dissemination of scientific knowledge and increase our understanding of medical informatics as a discipline. Additionally, we intend to produce and issue a core document stating the fundamental principles upon which all medical informatics journals editors should agree. The common goals will be identified and agreed on the scope and standard of papers that should be published in EFMI medical informatics journals. The reasons for setting out the statement are:

- To promote editorial excellence by enforcing the use of standards and guidelines (International Committee of Medical Journals Editors guidelines; Committee of Publication Ethics; other relevant documents [7]);

- To improve the quality of scientific studies published in EFMI medical informatics journals by imposing same standards for evaluating studies in medical informatics (guidelines already accepted as official EFMI document, but there were no further steps taken to ensure their use);

- To promote scientific publishing excellence by enforcing standards of paper formatting ('cameraready' manuscript format; Vancouver referencing style);

- To improve diffusion of scientific knowledge through the medical/ health informatics area (recognition and diffusion of EFMI research, education, clinical practice guidelines in EU countries should be promoted);

- To increase collaboration among EFMI medical informatics journal editors and schedule regular meetings of the Task Force;

- To explore the potential for using shared pool of reviewers, sharing information on review process and sharing expertise: technical editorial information, experiences, initiatives, publishing resources and tools (such as the open source Open Journal System or commercial/publisher solutions);

- To encourage articles not suitable for medical informatics journals to be published elsewhere and support the communication with editors of such journals;

- To provide a common voice when issues of common interest arise and enhance collaboration between national societies and EFMI bodies;

- To promote European initiatives in stimulating publications and top-quality research.

Acknowledgment. The authors would like to acknowledge the support of Jan Talmon from Maastricht University, Care and Public Health Research Institute, The Netherlands.

\section{REFERENCES}

1. Masic I, Novo A. History of medical informatics in Bosnia and Herzegovina. Acta Informatica Medica, 2007; 15(1): 49-61.

2. Collen MF. Fifty years in medical informatics. IMIA Yearbook of Medical Informatics. Methods of Information in Medicine, 2006; 45(Suppl. 1): S174-9.

3. Zvárová J. Symposium on "Biomedical Informatics and Biomedical Statistics Education". Methods of Information in Medicine, 2006: 45(3): 281-2.

4. Zvárová J. Biomedical Informatics Research and Education in the EuroMISE Center. IMIA Yearbook of Medical Informatics. Methods of Information in Medicine, 2006; 45(Suppl. 1): S166-73.

5. de Lusignan S. Introduction to the Primary Care Informatics Working Group of the European Federation for Medical Informatics (EFMI). Informatics in Primary Care, 2003; 11(3): 175-6.

6. de Lusignan S, Teasdale S. Achieving benefit for patients in primary care informatics: The report of an international consensus workshop at MedInfo 2007. Informatics in Primary Care, 2007; 15(4): 255-61.

7. Miller RA, Groth T, Hasman A, Safran C, Shortliffe EH, Haux R, McGray AT. On exemplary scientific conduct regarding submission of manuscripts to biomedical informatics journals. Methods of Information in Medicine, 2006; 45(1): 1-3.

Corresponding Author: Prof Izet Masic, MD, PhD, Medical Faculty, University of Sarajevo, Cekalusa 90/4, 71000 Sarajevo, Bosnia and Herzegovina; Tel: +387 33444 714; E-mail: imasic@lol.ba. 